\title{
Antichresis: a comparative study of classical Roman law and the contractual praxis from Roman Egypt
}

\author{
R. Bobbink \\ Ph.D.-candidate Roman Law and Legal History, Radboud University, \\ Department of Legal History, Montessorilaan 10, 6525 HR Nijmegen \\ R.Bobbink@jur.ru.nl \\ Q. Mauer \\ Ph.D.-candidate Roman Law and Juristic Papyrology, Leiden University, \\ Department of Legal History, Steenschuur 25, 2311 ES Leiden \\ Q.Mauer@law.leidenuniv.nl
}

\section{Summary}

The authors examine how papyrological sources from Roman Egypt written in Greek on antichresis relate to classical Roman law. Antichresis attested in papyrological antichretic contracts had a lot in common with antichresis emerging from Roman dispute resolutions. There was only one substantive difference: in classical Roman law, protection of the debtor was emphasized, whereas in the Greek papyrological antichretic contracts the position of the creditor was favoured. Given the similarities found, the authors conclude that antichretic loan both as an independent legal institution and as a pactum antichreticum was a pan-Mediterranean legal concept.

\section{Keywords}

Antichresis - ius in re - Hellenistic law - juristic papyrology - possessory pledge fruits

\section{Introduction}

The legal concept of antichresis $\left(\dot{\alpha} v \tau^{\prime} \chi \rho \eta \sigma \varsigma \varsigma\right)^{1}$ played a part in the granting of credit in the Roman Empire. In antichresis, a debtor grants a right to utilise an

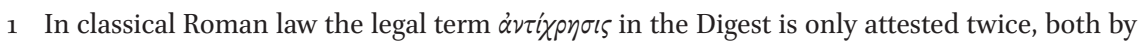


asset to his creditor. By utilising this asset the creditor gains a profit. This profit is considered to be either a payment on the secured debt, or to come in lieu of interest ${ }^{2}$. This antichresis had important economic advantages over a regular right of pledge that did not entail a right of use. For the debtor these advantages included that the secured debt was diminished by the value of the fruits of an estate or by the value of labour of a slave (see \$5.2). For the creditor a possible advantage was that in some cases he could circumvent the statutory interest rate, for example if the profit of a slave's services exceeded the maximum interest rate of $12 \%$ in Roman Egypt (see §5.1).

The presence of antichresis in Roman credit transactions is mainly reflected by responsa and imperial constitutiones in the Corpus Iuris Civilis. In this article we cite about thirty passages that are connected to antichresis. The source material in Aegyptus, one of Rome's provinces, exists in even larger numbers, well into the hundreds. The presence of antichresis in Roman Egypt does not emerge from the Corpus Iuris Civilis, but from transactional records that were drafted on papyri.

There are two striking differences in the nature of the Roman sources and that of the sources from Roman Egypt on antichresis. Firstly, most of the papyri show the beginning of a credit relationship. At the moment of origin of this relationship, the contracting parties reached an agreement on an antichretic loan. The lender and the borrower wrote down the deal on papyrus. The Roman materials show a later stage in a credit relationship. At this stage,

the Roman jurist Marcianus (second / third century AD) in Marc.D. 13,7,33 (Sing. Hyp.Form) and Marc.D. 20,1,11,1 (Sing. Hyp.Form). In the papyrological sources published it is attested in three 'accounting' documents. P. Gron. 11 (2nd cent. AD, provenance unknown), P. Prag. I 69 (5th-6th cent. AD, Arsinoite Nome) and P. Freer V (6th-7th cent. AD, provenance unknown). For P. Gron. 11 see also H. Kupiszewski, Antichrese und Nutzpfand in den Papyri, in: Iuris Professio, Festgabe für Max Kaser zum 8o. Geburtstag, ed. by H. Benöhr, Vienna 1986, p. 133.

2 A. Manigk, Gläubigerbefriedigung durch Nutzung, Ein Institut der antiken Rechte, Berlin 1910,

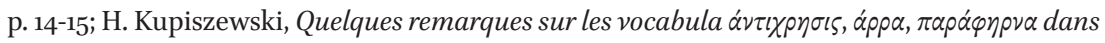
le Digeste, JJP 18 (1974), p. 229; M. Kaser, Besitzpfand und 'besitzloses' Pfand, [Studien zum römischen Pfandrecht, III ], SDHI 1979/47, p. 1-92 (reprinted in: M. Kaser, Studien zum römischen Pfandrecht, Napoli 1982, p. 128-220); D. Papadatou, Antichresis in Byzantine law, Revue des études byzantines, 66 (2008), p. 210; R. Bobbink, Antichresis, het vergeten zekerheidsrecht. Een historische vergelijking met het Franse recht, Groninger Opmerkingen en Mededelingen XXXIII (2016), p. 79-81. Unlike the works cited here before and in the first note, especially the works of Kupiszewski, this article aims to place the socio-economic phenomenon of antichretic loan in a broader Mediterranean context using the latest papyrological sources and an abundance of Roman legal sources. As to Roman law, the subject of (expressly created) antichresis is set out in a more elaborate way than in earlier literature. Notably, a relatively high number of antichresis fragments from the Corpus Iuris Civilis is analysed in the main text or referred to in the footnotes. Furthermore, the article contributes to the understanding of the socio-economic functions of antichresis and its emergence in Roman law and practice. 
the original agreement between the borrower and the lender had turned into disagreement. The arisen dispute was resolved by an imperial decree, a rescript of the imperial chancery or an advice of a private jurist.

Secondly, the Roman materials were not just individual dispute resolutions, they constituted applicable law in the entire Roman Empire, including Roman Egypt. The materials from Roman Egypt show a transaction practice in one of Rome's provinces, whether or not in accordance with the law.

In this article, we compare antichretic contracts from Roman Egypt with Roman dispute resolutions that relate to antichresis. We examine how papyrological sources from Roman Egypt written in Greek on antichresis relate to classical Roman law. To this end, we give a description of our source material $(\S 2)$. We then set out how in these sources a right of antichresis was created $(\S 3)$, which assets were encumbered with antichresis $(\S 4)$, what functions the right of antichresis could fulfil $(\$ 5)$ and what contractual rights and duties arose out of a right of antichresis ( $(6)$. The scope of this article is limited to the period of Roman occupation in Egypt. Furthermore, we do not investigate whether a right of antichresis could arise tacitly out of a right of pledge (also known as antichresis tacita). Papyri can inherently not provide us with an answer to this question.

\section{Sources}

\subsection{Sources from Old Babylonia, Assyria and Ptolemaic Egypt}

The application of the legal institution of $\alpha v \tau i x p \eta \sigma \iota s$ (antichretic loan) has waned in most civil law legal systems. It has however an impressive and ancient tradition. It was already in use at the time of the old Babylonians (first half of the second millennium BC $)^{3}$ and during the old Assyrian period ${ }^{4}$. Furthermore, the phenomenon of antichretic loan is documented extensively in the Kingdom of Arrapha, modern-day Kirkuk (Iraq). The corpus of contracts of antichretic loans from this kingdom contains over three hundred documents 5 .

3 Cf. R. Westbrook, The Old Babylonian Period, in: Security for debt in Ancient Near Eastern Law, ed. by R. Westbrook, Leiden 2001, p. 64-65. See also Papadatou, Antichresis in Byzantine law (supra, n. 2), p. 209 and Manigk, Gläubigerbefriedigung (supra, n. 2), p. 26.

4 Veenhof, The Old Assyrian Period, in Westbrook (supra, n. 3), p. 127ff, esp. p. 141. Cf. Kupiszewski, Quelques remarques (supra, n. 2), p. 229-230.

5 J.Justel, An Unpublished Nuzi-Type Antichretic Loan Contract in the British Museum; with some comments on children in the Kingdom of Arraphe, Iraq, 77 (2015), p. 134. 
BM 102353 (Nuzi, 1385-1360 BC), edited and published by J. Justel $(2015)^{6}$ is such a contract, more specifically on personal antichretic loan, which contains 'a person borrowing money or commodities from another hands over his property to the creditor, allowing its use and occupation in return for the interest on the property lent' ${ }^{7}$. In Ptolemaic Egypt of the Hellenistic period ${ }^{8}$, Greek papyri as early as the third century BC show antichretic loan agreements. In the following Ptolemaic legal document a Greek and a (descendant of a) Thracian ${ }^{9}$ agreed upon an antichretic loan. The papyrus is from the Corpus Papyrorum Raineri:

CPR XVIII 18, 368-374 (3rd cent. BC, Kalliphanous):

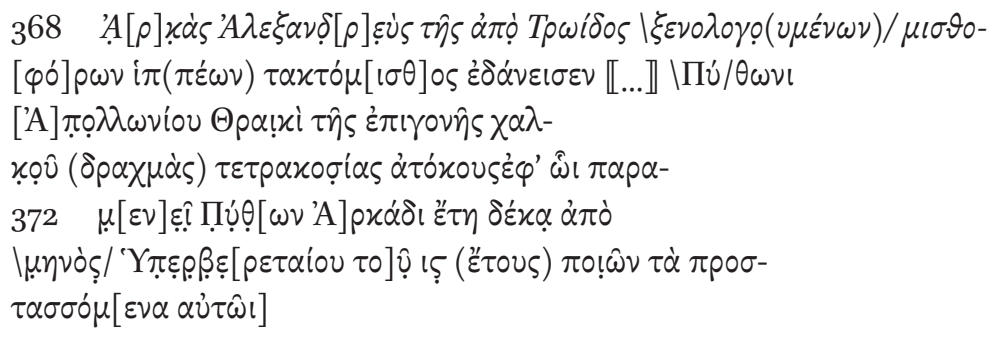

Arkas, from Alexandria Troas, Taktomisthos of the hired cavalrymen has lent four hundred bronze drachmae to Python son of Apollonius, of Thracian origin, without interest, under the condition that Python remains with Arkas for ten years starting in the month of Hyperberetaios in the 16 th year, doing what he is told to $\mathrm{do}^{10}$.

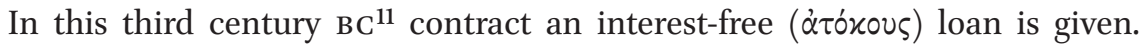
Python, who is a free man and no slave, has to remain at the creditor's house

$6 \quad$ See also M. Maidman, The Nuzi Texts of the British Museum, Zeitschrift für Assyriologie und vorderasiatische Archäologie, 76 (1986), p. 283.

7 Justel, Unpublished Loan Contract (supra, n. 5), p. 134.

8 By 'the Hellenistic period', the timeframe between the death of Alexander the Great and the Roman incorporation of Egypt (323 BC - 30 BC) is meant.

9 Thracians belonged to a special subgroup in Ptolemaic Egypt. It is known that Thracians came to Ptolemaic Egypt as mercenaries. In this capacity they were, according to Bingen, a mayor component of the Hellenophone power structure and this helped to create mutual solidarity between Thracians, the Ptolemaic kings, Greeks and Macedonians. J. Bingen, Hellenistic Egypt, Monarchy, society, economy, culture, Los Angeles 2007, p. 92. In

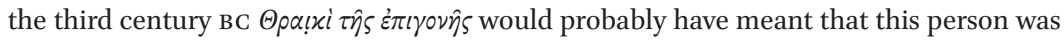
of (ethnic) Thracian descent.

10 All translations from Latin into English and from Greek into English have been made by Q. Mauer.

11 For other 3 rd century BC contracts of antichretic loan see: P. Yale I 26 (300-276 BC, Herakleopolites), P. Hamb. IV 239 (276-226, Tholtis), BGU XIV 2395 (221 BC, Takona), BGU 
himself to provide labour for ten years. According to Jördens ${ }^{12}$ the four hundred drachmae has been given in full, instead of a partial payment ${ }^{13}$.

\subsection{Sources from Roman Egypt}

In and directly after the first century вС after the Roman conquest of Egypt, a Roman presence can be deduced in two antichretic documents. Firstly, PSI X 1120 (25 BC-25 AD, provenance unknown). In this contract three parties, Herakleitos, Gaius and Lucius agree upon a loan under the condition of paramonè ${ }^{14}$, in which a slave or a free person is placed with the creditor in order to perform services. The second contract is the fragmentary, multilingual papyrus document SB XII $11041^{15}$ (2O-21 AD, Tebtynis). In this contract a Roman man named Gaius Iulius Fuscus, agreed to be a creditor of an antichretic loan of eighty four

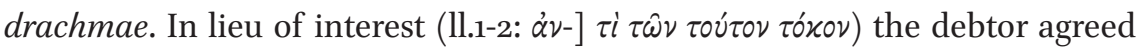
upon $\tau \dot{\eta} \nu \dot{\varepsilon} v o i x \eta \eta \omega \nu$ (1. 7), a right of habitation of his house and courtyard (1l. 4-5), which the creditor himself, his heirs or representatives could inhabit rent-free. Alternately he could rent it out. Later, the loan had been paid and the document was transferred to the debtor in ll. 16-18:

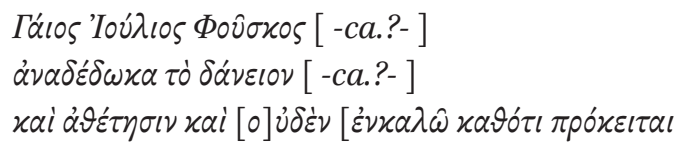

Gaius Julius Fuscus .... I have surrendered the loan document to be terminated and in no manner will I claim anything as written above.

X 1964 (221-213, Tholtis), P. Frankf. I (213 BC Tholtis) and BGU VI 1280 (210 BC, provenance unkown). For antichretic loan in the second century вС see for example the following three documents from Philadelphia: P. Freib. III 28 (179-178 вС), 25 (178 вС) and 34 (173 BC).

A. Jördens, B. Kramer, Das Vertragsregistervon Theogenis (CPR XVIII), Chronique d'Egypte, 67 (1992), p. 356. Cf. BL x 62.

In case of partial payment the rest of the sum, i.e. the part of the 400 drachmae, which was not given, is considered to be the interest.

A contract of paramonè as a form of antichretic loan is mostly used by contracting parties to substitute a certain rate of interest for an amount of labour. In this type of antichresis a debtor would provide his creditor with either a slave, a libertus or even his own son or daughter, so that the creditor could use this person's labour. Cf. Kupiszeski, Antichrese (supra n. 1), p. 146-149.The term paramonè is, however, also used for other types of contracts. One of these is a specific type of labour contracts, of which the so called 'wet-nurse contracts', e.g. SB XVIII 13120 (80-81 AD, Oxyrhynchus), are the most well-known. See A. Bertrand, Paramoné und verwandte Texte, Studien zum Dienstvertrag im Rechte der Papyri, Berlin 1964, p. $39 \mathrm{ff}$. 
Both documents show that in the early period of Roman Egypt starting from 3 о BC Romans (Gaius and Lucius in the first contract and Gaius Julius Fuscus in the second) participated in legal transactions with local inhabitants. In the loan documents PSI X 1120 and SB XII 11041 Roman citizens dealt with the natives Herakleios and Psenkebkis and Marheus respectively. They adopted the legal institution of antichresis, which has not been apparent from other Roman (legal) sources in this timeframe.

\subsection{Roman sources until 3rd century $A D$}

The above shows that Romans present in Roman Egypt secured credits via the legal institution of antichresis in the first century BC. In Rome, however, antichresis is only mentioned in sources dating from the third century AD onwards ${ }^{16}$. It is probable that antichresis had its inception in Roman law at the beginning of the third century. It must be stated first and foremost though, that a large majority of fragments in the Digest was written by Paulus, Papinianus, Ulpianus and later jurists ${ }^{17}$. Furthermore, sources about the law of security dating before Julianus, the editor of the edictum perpetuum who served under Hadrian between 117 and 138, are especially scarce. Therefore, for the most part the Digest was compiled out of works dating from the third century or later.

That the Corpus Iuris Civilis does not provide us with texts about antichresis older than the third century, does not mean that these texts did not exist at the time. It may well be that such sources about antichresis did exist in Rome before the third century, but that these sources are lost. Indications that might confirm this suggestion lie in the concept of nexum and two fragments by Julianus and Florentinus.

The legal concept of nexum, which shows resemblance to a Hellenistic form of antichresis, namely paramonè, was an act by which a creditor acquired an immediate right to the services of and control over a free man for the purpose of repaying a debt. The institution became obsolete as a result of the Lex Poetelia, which was enacted at the end of the fourth century ${ }^{\mathrm{BC}^{18}}{ }^{18}$. In spite of the abolition of nexum, it appears that a debtor's children were in practice the ob-

16 A possible reference to antichresis in the first century in Pompeii is the Mancipatio Pompeiana from CIL IV 3340,155: K. Verboven et al., Pistoi dia tèn technèn, Bankers, loans, and archives in the ancient world, in: Studies in honour of Raymond Bogaert, Leuven 20o8, p. 196 and 471.

17 J.E. Spruit, R. Feenstra, Inleiding, in: Spruit, Feenstra, Bongenaar (ed.), Corpus Iuris Civilis, Tekst en vertaling: Digesten 1-10, Den Haag 1994, p. XXI-XXII.

18 About nexum, see G. Mac Cormack, The «Lex Poetelia», Labeo, 19 (1973), p. 306-317; A. Watson, Rome of the XII Tables, Person and Property, Princeton NJ 1975, p. 111-124. An elaborate literature survey is given by M. Kaser, Das römische Privatrecht, Erster Abschnitt: Das altrömische, das vorklassische und klassische Recht, München 1971, p. 166, n 2. 
ject of an antichretic right of pledge up to the reign of Justinian. In 556 he issued Just.Nov. 134,7. This Novella criminalised the use of (free) children as an antichretic pledge. A creditor who committed this offence could be sentenced to corporal punishment ${ }^{19}$. Since Nexum was abolished before the Roman conquest of Egypt, it falls outside of the timeframe of our research.

An early text that could be interpreted as a legal opinion on antichresis is Jul.D. 8,1,16 $6^{20}$ :

Ei, qui pignori fundum accepit, non est iniquum utilem petitionem servitutis dari, sicuti ipsius fundi utilis petitio dabitur. idem servari convenit et in eo, ad quem vectigalis fundus pertinet.

It is not unjust that an actio utilis to recover a servitude is given to him, who accepts an estate in pledge, as will be the case when the actio utilis is given to recover the land itself. It is agreed that the same action is preserved for him, to whom the right of long lease of an estate belongs.

In this text a servitude was granted in favour of an estate, which was later pledged. The pledgee was granted an action to claim the servitude. This might imply that the pledgee was entitled to exercise a right attached to the pledged estate: the pledgee was entitled to exercise a right of servitude. The wording of non est iniquum in the text implies that there has been discussion among the jurists and that this was eventually the consensus of these jurists. Furthermore, the text does not state that the pledgee gained any profit by exercising the right of servitude that decreased the secured debt or came in lieu of interest. It merely states that the pledgee was granted an action from the right of servitude. This could also imply that the pledgee was not authorised to exercise the right of servitude. He was only granted an action so he could prevent the right of servitude from extinguishing, which would lead to a decline in value of the pledged estate. Thus, the pledgee could only bring an action in order to retain the value of the object pledged to him.

The second text that possibly concerns antichresis is Flor.D. 13,7,35,1:

Pignus manente proprietate debitoris solam possessionem transfert ad creditorem: potest tamen et precario et pro conducto debitor re sua uti.

19 Papadatou, Antichresis in Byzantine law (supra, n. 2), p. 214-215. See also the following earlier sources on the sale and encumberance of children of free men in general: Paul.D. 20,3,5; Diocl.Max.C. 4,43,1; Const.C. 4,43,2; C.Th. 3,3,1; C.Th. 5,10,1. 
Pledge transfers only the possession to the creditor, as the legal title remains with the debtor: even though the debtor can still be using his own goods as precarium or if it is leased back to him.

According to this text a pledgee could give a pledged object in precarium or locatio-conductio to the pledgor. The power to rent out the pledged object was one of the most important powers that resulted from the right of antichresis. This text by Florentinus might therefore indicate that the right of antichresis was recognised in Roman law even before the third century. On the other hand, the text only refers to the power to rent out the pledged object to the pledgor, not to third parties. First the debtor gives an object in possessory pledge to the creditor, then he regains control of the object by leasing it back. Thus, the text might as well only cover an early way to establish a non-possessory pledge and not concern the right of antichresis at all. Furthermore, as was the case with the text by Julianus, the text does not mention that the pledgee gained any profit that decreased the secured debt or came in lieu of interest.

Having said this, there is no source in the Corpus Iuris Civilis dating before the third century that is unambiguously about antichresis. Furthermore, it is likely that Gaius was not aware of the legal concept of antichresis ${ }^{21}$. Gaius lived in the period of time between the Emperor Hadrian and Marcus Aurelius. Gaius probably died in about the year 18 o. In Gai.D. $47,2,55$ he emphatically declared that use of a pledged object made by the pledgee would result in liability for theft:

Si pignore creditor utatur, furti tenetur.

If a creditor uses a pledge, he is liable for theft.

Alternately, one could interpret this text in a restrictive sense in that antichresis was not categorically ruled out. In Gaius's time antichresis might not have been forbidden; the pledgee was merely not authorised to use the security object in the case at hand. In that case, the creditor was indeed liable for theft, but Gaius might have come to a different conclusion under different circumstances $^{22}$.

21 Cf. Papadatou, Antichresis in Byzantine law (supra, n. 2), p. 210-212.

22 R.J. Goebel, Reconstructing the Roman law of real security, Tulane Law Review, 36 (1961), p. 34; Papadatou, Antichresis in Byzantine law (supra, n. 2), p. 211-212. 


\section{$2.4 \quad$ Roman sources from the 3rd century AD onwards}

It thus looks like antichresis only started to play a role in Roman law and society after Gaius's time, at the commencement of the third century ${ }^{23}$. The oldest text about antichresis in the Codex Justinianus was issued by Antoninus Caracalla in 207. He and Alexander Severus, who became emperor five years after Caracalla's death, enacted most of the rescripts concerning antichresis. In the chancery of Caracalla and his predecessor Septimius Severus served the jurists Paulus, Papinianus and Ulpianus. They are the authors of the oldest and the most fragments about antichresis in the Digest.

In the Corpus Iuris Civilis there are only two fragments that explicitly men-

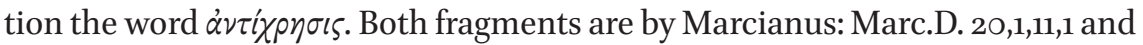
Marc.D. $13,7,33^{24}$. However, many more texts in both the Digest and the Codex Justinianus mention the phenomenon that is now commonly known as antichresis (even though the word was never written in Latin in classical Roman

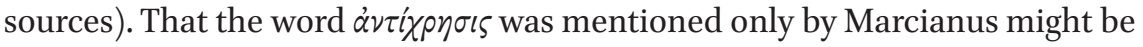
explained by the Greek background of this jurist ${ }^{25}$. He might have wanted to introduce the Greek word antichresis to describe a phenomenon that was already known in Roman law, but not under a specific Latin term. Another explanation is that Marcianus discovered the legal concept of antichresis in Greek/ Hellenistic law and wanted to introduce it in Roman law and practice. However, the materials studied for this paper do not support the latter hypothesis.

Roman sources in the fourth and fifth century remained silent concerning antichresis. However, in the sixth century several Byzantine Novellae concerning antichresis were issued by Justinian ${ }^{26}$. Just.Nov. 120,4 concerned the antichretic right of pledge over property belonging to (among others) the Hagia Sophia Cathedral in Constantinople ${ }^{27}$. The pledgee's right to use the security object was emphasized. This antichretic pledge primarily aimed to enable the creditor to recover his loan by reaping the fruits of the property. Thus, the value of the fruits gradually satisfied the pledgee's claim:

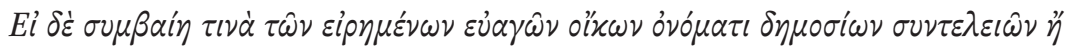

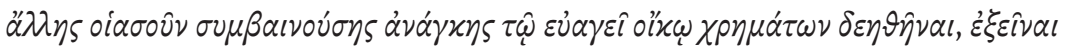

23 On the continuity of imperial legal activity in the third century, see A.J.B. Sirks, Das Recht der Soldatenkaiser, in: U. Babusiaux, A. Kolb (ed.), Das Recht der 'Soldatenkaiser', Berlin 2015, p. 31-45.

24 Cf. Kupiszewski, Antichrese und Nutzpfand (supra n. 1), p. 134.

25 P. Frezza, Le garanzie delle obbligazioni, Corso dritto Romano, Volume secondo: Le garanzie reali, Padova 1963, p. 359; F. Schulz, History of Roman legal science, Oxford 1963, p. 295 -296.

26 Just.Nov. 120,4; Just.Nov. 120,6,2.

27 Papadatou, Antichresis in Byzantine law (supra, n. 2), p. 212. 


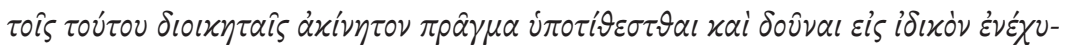

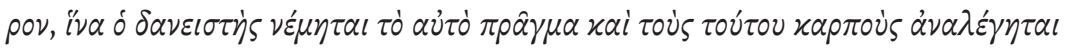

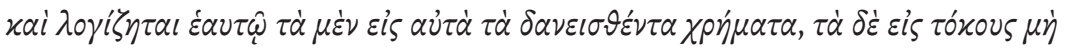

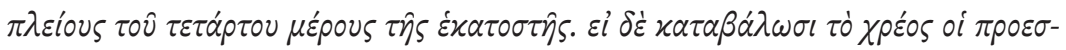

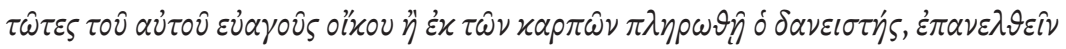

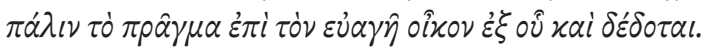

If it occurs that one of the sacred houses previously mentioned regarding public taxes or another emergency of the sort, which befalls that sacred house, is in need of funds, it is possible for the administrators of this building to place real property under hypothec and to pledge it in a special way, so that the creditor will be allotted this property and that he to his own benefit enjoys the fruits and deducts it in part from the capital and in part from the interest, which does not amount to more than one percent quarterly. If the administrators of this sacred house repay the capital or the creditor is paid in full by the fruits, the property must be reinstated to the sacred house from which it was given.

Churches could obtain real estate, for example through gifts or inheritances 28 . However, a church was prohibited from alienating or pledging its assets ${ }^{29}$. Therefore, a church could not apply its real estate as security to raise funding ad pias causas ${ }^{30}$. The above Novella provided an exception. It allowed a church to take out a loan secured by an antichretic right of pledge. Until the loan was repaid, the creditor could gradually satisfy his claim out of the fruits of the encumbered real estate. Thus, a church could apply real estate as security, without running the risk of losing its ownership by execution in case of default ${ }^{31}$. The function of antichresis in this Novella was amortization. If a church would instead grant a right of interest antichresis over its real estate as security, the transaction could turn out to be a lucrative investment for the creditor. As shown in paragraph 5.1, interest antichresis enabled the creditor to lend money against a profit larger than statutory interest rates.

28 M. Kaser, Das römische Privatrecht, Zweiter Abschnitt: Die nachklassischen Entwicklungen, München 1975, p. 158, 467 and 488; E. Patlagean, Pauvreté économique et pauvreté sociale. 4e-7e siècles, Paris 1977, p. 273-275 and 195.

29 Just.C. 1,2,21; Just.Nov. 7.

30 Kaser, Das römische Privatrecht, Zweiter Abschnitt (supra, n. 28), p. 243-244; Patlagean, Pauvreté (supra, n. 28), p. 195-196 and 291-292.

$31 \quad$ For other exceptions see Just.Nov. 46; Just.Nov. 65; Just.Nov. 131,13; Patlagean, Pauvreté (supra, n. 28), p. 292. 
Furthermore, four Justinian Novellae addressed cases of abuse by antichresis creditors. As stated above, Just.Nov. 134,7 criminalised the use of (free) children for the purpose of antichresis. In addition, Just.Nov. 32-34 addressed abusive overinsurance of secured creditors ${ }^{32}$. The Novellae issued by Justinian demonstrate plausibly that antichresis was still in use during the fourth and fifth century, even though it was not mentioned in legal sources from that timeframe. What is more, Justinian's measures to protect debtors suggest that abuse of antichresis by creditors had been building up to the sixth century without legislative interference.

The Roman-Egyptian materials on the other hand, show a remarkable continuity. After the Constitutio Antoniniana, all the free inhabitants of Roman Egypt became Roman citizens and were subsequently subjected to Roman law. The antichretic loans in contracts, however, seem almost unaffected by the major change brought by this constitution. From the first century вС until the Arabic conquest, sources concerning antichresis are readily available for every century 33 .

The Roman right of antichresis could be created in three forms. Firstly, antichresis could be established as part of a possessory right of pledge (pignus). Secondly, antichresis could arise with a fiduciary transfer (fiducia cum creditore). The right of antichresis arose as part of a fiducia cum creditore when the possession of the collateral was transferred to the creditor along with the right of ownership. In that case, the right of antichresis was a result of the creditor's right of ownership ${ }^{34}$. By contrast, the fiduciary right of ownership may not always have been sufficient to entitle the security owner to use the security

$32 \quad$ See paragraph 6.3 below.

33 See the antichretic documents of BGU I 339 (128 AD, Karanis), P. Diog. 16 (207 AD, Arsinoites), P. Gen. II 112 (384 AD, Philadelphia), P. Köln II. 102 (418 AD, Oxyrhynchus), P. Michael 42A-B (566 AD, Aphrodites Kome) and P. Köln viI 322 (VI-VIII AD, Herakleopolis).

34 PS. 2,13,2; Manigk, Gläubigerbefriedigung (supra, n. 2), p. 59; W. Erbe, Die Fiduzia im römischen Recht, Weimar 1940, p. 78; M. Kaser, Studien zum römischen Pfandrecht, II: Actio pigneraticia und actio fiduciae (Zweiter Teil, §§ VII-VIII), TvR 47 (1979), p. 333, Fn 294 (reprinted in: M. Kaser, Studien zum römischen Pfandrecht, Napoli 1982, p. 59-125; p. 113); Kaser, Besitzpfand (supra, n. 2), p. 84; G. Noordraven, Die Fiduzia im römischen Recht, Amsterdam 1999, p. 229. See also the following fragments that might originally have covered fiducia: Ulp.D. 13,7,25. About this text: O. Lenel, Palingenesia Iuris Civilis, Leipzig 1889, p. 1027; Noordraven, op. cit. (this footnote), p. 269 ff. Ulp.D. 13,7,22pr; Ulp.D. 13,7,22,2. 
object. In that case, a clause in the security agreement was necessary to permit the creditor to use the object of security. An example of this is provided by Pap. D. 33,10,9,2. According to Lenel and Noordraven, this text was originally about a fiduciary security transfer and not about pledge ${ }^{35}$. This is indeed likely, since the question whether the silverware in the text belonged to the inheritance would make a lot more sense if the testator were the security owner than if he merely were a pledgee:

Supellectili sua omni legata acceptum argentum pignori ${ }^{36}$ non continebitur, quia supellectilem suam legavit, utique si non in usu creditoris id argentum voluntate debitoris fuit, sed propositum propter contractus fidem ac restituendae rei vinculum.

When someone bequeaths all his household goods, the silverware he accepted as a pledge ${ }^{37}$, will not be included, because he bequeathed his own household goods, and certainly so if this silverware was not used by the creditor with consent of the debtor, but was intended to enforce the contractual duties and to enforce the restitution of the goods.

In this fragment, reading the word pignori for fiduciae as suggested by Lenel and Noordraven, the testator received silverware in fiduciary security ownership. Apparently, the testator was not authorised to use the silverware, so he stowed it away. Thus, even though he was the security owner of the silverware, the testator was prohibited from using it. On the other hand, the creditor would have been entitled to use the security object if the debtor had given his consent thereto.

Thirdly, antichresis could be created as an independent real right, without establishing a right of pignus or a fiduciary transfer. The creditor could commence to make use of his right of antichresis either upon creation, or after the occurrence of default of the debtor ${ }^{38}$.

Antichretic loan in Roman Egypt is attested both as an independent legal institution ${ }^{39}$ and as an institution combined with the right of pledge, so the

about these texts: Lenel, op. cit. (this footnote), p. 618; Noordraven, op .cit. (this footnote), p. 229-23o.

35 Lenel, Palingenesia (supra, n. 34), p. 914; Noordraven, Fiduzia (supra, n. 34), p. 162-163.

36 Lege: fiduciae.

37 Lege: fiduciary security ownership.

38 Manigk, Gläubigerbefriedigung (supra, n. 2) p. 55; Kupiszewski, Quelques remarques (supra, n. 2), p. 23o-231; Kaser, Besitzpfand und 'besitzloses' Pfand (supra, n. 2), p. 83-85. 
pledged objects could be used by the creditor. A link between a Hellenistic legal institution such as $\pi p \hat{\alpha} \sigma \iota \xi \dot{\varepsilon} \pi i \lambda \dot{v} \sigma \varepsilon l$, which is a legal concept comparable to the Roman fiducia cum creditore and antichresis cannot be established in sources from Roman Egypt. Furthermore, antichretic loan could function as a penal clause (antichrèse de retard) ${ }^{40}$ as is the case in SB XIV $12017(156 \mathrm{AD}$, Tebtynis) ${ }^{41}$. The creditor in this case, a woman named Aretiaine, could to her own benefit grow crops on the land as antichrèse de retard ${ }^{42}$, if the principal sum was not paid in time.

\subsection{Antichresis combined with pledge}

In Rome, the right of antichresis became part of a right of pignus if the contracting parties added an accessory clause (pactum adiectum) to the contract of pledge. The accessory clause entitled the pledgee to exercise the right of antichresis ${ }^{43}$. In secondary literature this pactum adiectum has become known as the pactum antichreticum ${ }^{44}$. The right of antichresis was protected by the praetor with all legal remedies that were available to the pledgee. The pledgee could bring an actio Serviana or a possessory interdict for recovery of the

of the xIxth congress of papyrology, Cairo 2-9 September 1989, edited by A. El-Mosalamy, Cairo 1992, p. 271-272. Cf. C. Kreuzsaler, Loan contracts serving other purposes, in: Law and Legal Practice in Egypt from Alexander to the Arab Conquest, edited by J. Keenan, Cambridge 2014, p. 267.

40 In BGU I 339 (128 AD, Karanis) an instance of antichrèse de retard is attested in lieu of interest and in P. Tebt. II 390 ( $167 \mathrm{AD}$, Tebtynis) antichrèse de retard in lieu of interest and in combination with a right of hypothec is attested (See Manigk, Gläubigerbefriedigung (supra, n. 2), p. 29, 31). From the three contracts mentioned it can be stated that the institution of the antichrèse de retard could either function independently or combined with a right of pledge / hypothec. The term antichrèse de retard is derived from Kupiszewski, Quelques remarques (supra n. 2), p. 230-231.

M. de Kat Eliassen, Three Papyri from the Oslo Collection, Symbolae Osloenses, $5^{1}$ (1976), p. 15 off.

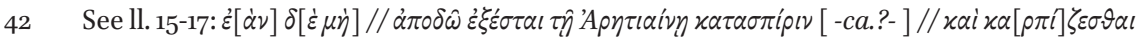

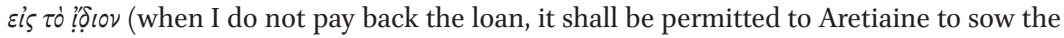
lands and reap the fruits to her own benefit). The debtor Tabous was spared this fate, as the contract had been crossed out, indicating that she paid the principal sum.

43 Phil.C.4,32,17; Ulp.D. 2,14,52,1; Marc.D. 13,7,33; Mod.D. 13,7,39; Pap.D. 20,1,1,3; H. Dernburg, Das Pfandrecht nach den Grundlagen des heutigen römischen Rechts, Zweiter Band, Leipzig, p. 67; Manigk, Gläubigerbefriedigung (supra, n. 2), p. 51; Frezza, Le garanzie (supra, n. 25), p. 199; Kupiszewski, Quelques remarques (supra, n. 2), p. 232; Kaser, Besitzpfand (supra, n. 2), p. 80; Papadatou, Antichresis in Byzantine law (supra, n. 2), p. 210.

44 See for instance: Manigk, Gläubigerbefriedigung (supra, n. 2) p. 51; Frezza, Le garanzie (supra, n. 25), p. ; Kupiszewski, Quelques remarques (supra, n. 2), p. 232. 
pledge ${ }^{45}$. Furthermore, the pledgee could fend off actions of others who sought to prohibit the pledgee from utilising the pledge, including the pledgor and owner. To this end, the pledgee was given an exception ${ }^{46}$.

The Roman-Egyptian variant of the pactum antichreticum is reflected in P. Lond. III 1168 (44 AD, Hermoupolis Magna). In this contract a debtor pledged six shares of a house from a total of seven and gave the creditor the right of habitation. In three parchment documents from Dura-Europos in Roman Syria, namely P. Dura. 20 (121 AD, Dura), P. Dura. 21 (II AD, Dura) and P. Dura. 23 (134 AD, Dura) antichretic loan was combined with pledge or hypothec ${ }^{47}$. P. Mich. Inv. $4000^{48}$ (180 AD, Diospolis Inferior) contains correspondence between the Roman dioicetes Julius Crispinus and later Vessidius Rufinus ${ }^{49}$ and a creditor $^{50}$ / plaintiff concerning an antichretic loan combined with a pledge. This combined legal concept was, as appears from the contract, so robust that it had preference over protopraxia by the state ${ }^{51}$.

\subsection{Antichresis as an independent real right}

In Roman Egypt, an independent right of antichresis is found more often in the papyri than $\alpha \dot{v} \tau i x p \eta \sigma \iota s$ combined with the right of pledge ${ }^{52}$. The independent antichretic loan is frequently attested in the form of żvoix $n \sigma i \zeta$ (right of habitation). Without a right of pledge, the antichretic creditor could occupy a (part of the) debtor's house or rent it out to third parties. This institution is attested in Greek papyri from third century вC Ptolemaic Egypt ${ }^{53}$ in BGU XIV 2395 (222221 BC, Takona) up until third century AD Roman Egypt in for example P. Princ.

45 Jav.D. 41,3,16; F. Schulz, Classical Roman Law, Oxford 1951, nr. 706a and 753; Goebel, Reconstructing (supra, n. 22), p. 34.

46 Marc.D. 20,1,11,2; J. Kohler, Pfandrechtliche Forschungen, Jena 1882, p. 73-76.

47 For contracts of later date see: P. Euphrates 13 (243 AD Beth Phouraia) and P. Michael. 42A (566 AD, Aphroditopolite).

48 The papyrus only has an inventory number. The papyrus was published in 2018 in: A. Connor and T. Coughlan, Antichresis and Dioikesis, Negotiating Public and Private Debt in the Egyptian Delta, ZPE 205 (2018), p. 217-227.

49 His name can also be Vestidius. Cf. Connor and Coughlan (supra, n. 48), p. 223.

50 The creditor Ammonios, not being the original plaintiff in this case, inherited his claim from his (grand)mother Tapiomis.

$5^{1} \quad$ Protopraxia or $\pi \rho \omega \tau 0 \pi \rho \alpha \xi i \alpha$ is the right of the fiscus to recover money from a debtor as the first privileged creditor. According to Kaser influences of the Hellenistic East can be seen in this right. Kaser Das römische Privatrecht, Erster Abschnitt (supra, n. 18), p. 179. This right is well attested in the papyri of the second and third century AD. See, for example, BGU VII 1573, 15 (141 AD, Philadelphia).

$5^{2} \quad$ Rupprecht, Zur Antichrese (supra, n. 39), p. 267.

53 See also the contracts: BGU VI 1280 (III BC, Provenance Unknown), P. Stras. II 92 (244-243 BC, Oxyrhynchus) and BGU X 1964 (221-203 BC, Provenance Unknown). 
III 144 (219-? AD, Ptolemais Euergetis), although most of these contracts are from the first and second century AD, e.g. the crossed-out SB VIII 13042 (29 AD, Oxyrhynchus) and P. Mich. XI 605 (AD 117, Bacchias). An early 'Roman' case of this institution can be found in BGU IV $1053^{54}$ (13 BC, Alexandria), in which the imperial freedman ${ }^{55}$ Gaius Iulius Philios ${ }^{56}$ gave three parties an interest-free loan of three hundred drachmae in Ptolemaic silver. Not only was he via the contract entitled to repayment of one drachma per day for the duration of three hundred days, he could also make use of the wood shop belonging to the debtors during the term of the loan.

Under Roman law, parties could establish an independent right of antichresis by entering into an agreement of antichresis and transferring possession of the relevant objects to the creditor ${ }^{57}$. Unlike the right of pledge, this independent right of antichresis did not award a right of foreclosure to the creditor. Nor did the creditor rank first for payment of the proceeds of a foreclosure sale. An independent right of antichresis only conferred the right to utilise the object given in antichresis ${ }^{58}$. The value created by utilising the antichresis property diminished the secured debt or came in lieu of interest ${ }^{59}$. Interestingly, the creditor thus appeared to have a right of use which was contingent to his claim.

The independent right of antichresis was equal to a real right ${ }^{60}$. The creditor could uphold his independent right of antichresis against the debtor, as well as against third party-possessors ${ }^{61}$. Marc.D. 20,1,11,1 shows that under property law the position of the antichresis creditor was analogous to the position of the pledgee $^{62}$ :

54 See the revised version of Van Minnen in P. van Minnen, An Antichretic Loan from Early Roman Alexandria Revisited (BGU IV 1053), ZPE 199 (2016), p. 144-154.

55 Cf. van Minnen (supra n. 54), p. 145. See also: A. Bowman, Some Romans in Augustan Alexandria, BSAA 46 (2000), p. 13-24.

56 The same Gaius Iulius Philios is known from other papyri: BG U IV 1149 (13 BC, Alexandria), 1151 (13 BC, Alexandria), 1156 (16-15 BC, Alexandria) and 1166 (13 BC, Alexandria).

57 Diocl.C. 8,42(43),20; Marc.D. 20,1,11,1; Alex.C. 4,32,14; Val.Gall.C. 4,26,6. Manigk, Gläubigerbefriedigung (supra, n. 2) p. 48-51; Kupiszewski, Quelques remarques (supra, n. 2), p. 230; Kaser, Besitzpfand (supra, n. 2), p. 86-88.

$5^{8} \quad$ Kohler, Pfandrechtliche Forschungen (supra, n. 46), p. 71.

59 Manigk, Gläubigerbefriedigung (supra, n. 2), p. 48-51; Kupiszewski, Quelques remarques (supra, n. 2), p. 23o; Kaser, Besitzpfand (supra, n. 2), p. 86-88.

6o Manigk, Gläubigerbefriedigung (supra, n. 2) p. 48-49; Kupiszewski, Quelques remarques (supra, n. 2), p. 230-231; Kaser, Besitzpfand (supra, n. 2), p. 85-87. Contrary: Kohler, Pfandrechtliche Forschungen (supra, n. 46), p. 92-93.

61 Kupiszewski, Quelques remarques (supra, n. 2), p. 231; Kaser, Besitzpfand (supra, n. 2), p. 87; Cf. Manigk, Gläubigerbefriedigung (supra, n. 2), p. 49.

62 Cf. Dernburg, Pfandrecht (supra, n. 43), p. 93. 


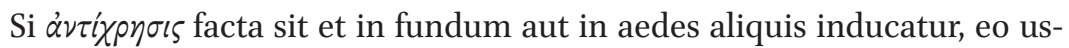
que retinet possessionem pignoris loco, donec illi pecunia solvatur, cum in usuras fructus percipiat aut locando aut ipse percipiendo habitandoque: itaque si amiserit possessionem, solet in factum actione uti.

If an agreement of antichresis is made and someone is brought into the land or the house, he continuously retains the possession as if it were a pledge, until the money has been paid to him, because he receives the fruits in lieu of interest either by renting it out or by receiving them himself by living in it: therefore if he has lost possession, he is wont to bring an actio in factum.

The term pignoris loco shows that the independent right of antichresis was treated analogously to the right of pledge ${ }^{63}$. Therefore, the creditor could recover the antichresis assets with a possessory interdict ${ }^{64}$ or an actio Serviana in factum $^{65}$. Further evidence that the Roman independent right of antichresis was equal to a real right is attested in Val.Gall.C. 4,26,6:

Si servus tuus sine permissu tuo accepta pecunia mutua in usurarum vicem habitandi facultatem concessit, nullo iure adversarius tuus hospitium ex hac causa sibi vindicat, cum te servi factum non obligaverit: et ingrediens rem tuam contra vim eius auctoritate competentis iudicis protegeris.

If your slave, having accepted money as a loan for consumption, without your permission has granted a right of habitation in lieu of interest, your opponent claims with no right derived from this cause a right of residency for himself, because the act of a slave will not put you under any obligation: and entering your property you will be protected against his violence by authority of a competent judge.

63 Kaser, Besitzpfand (supra, n. 2), p. 84.

64 H.H. Runia, Bescherming van Bezit, Een rechtshistorische en leerstellige studie naar de wortels en de totstandkomingsgeschiedenis van de huidige regeling in art. 3:125 BW, Den Haag 2016, p. 58 .

65 Kaser, Besitzpfand (supra, n. 2), p. 87; Manigk, Gläubigerbefriedigung (supra, n. 2), p. 49. On the actio Serviana, see Schulz, Classical Roman Law (supra, n. 45), nr. 706a-711; G. Krämer, Das besitzlose Pfandrecht, Entwicklungen in der römischen Republik und in frühen Prinzipat, Köln-Weimar-Wien 2006, p. 38-39; H.L.E. Verhagen, The evolution of pignus in classical Roman law, Ius honorarium and 'ius novum', TvR 81 (2013), p. 59. 
In this fragment the debtor borrowed money from a creditor. Then, without the authority to do so, the debtor's slave created a right of antichresis: the right of habitation in lieu of interest. The creditor then brought a vindicatio, which signals that the creditor tried to sue with a real action ${ }^{66}$. According to Kaser, this action was derived from the vindicatio servitutis. Alternately, the action may have been derived from the vindicatio pignoris, which would be in accordance with the actio Serviana in factum attested in Mar.D. 20,1,11,1. Since the creditor brought a real action, he also had a corresponding real right of antichresis $^{67}$.

Both in Roman-Egyptian and classical Roman legal sources, antichresis was typically established on houses, land, slaves or limited real rights thereon.

\subsection{Immovable property}

A share of a house in the province of Roman Egypt was mentioned as one of the objects of antichretic loan ('ंvoíx 1168. Egyptian lands suited for agricultural purposes could be objects for antichresis, which is attested in a variety of documents ranging from early Ptolemaic times, such as P. Frankf. I (214-213 B C, Tholtis), until well into the Byzantine era e.g., P. Köln VII 322 (VI-VIII AD, Herakleopolis). In these instances the cred-

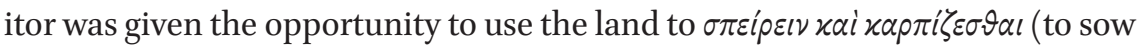
and reap the fruits), during the term of the lease:

BGU I 101 (115 AD, Arsinoites 2-9)68:

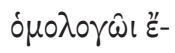

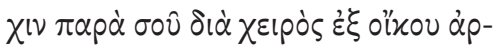

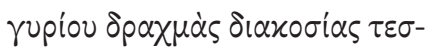

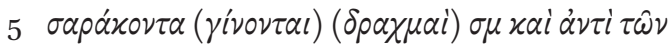

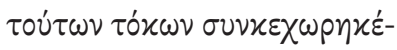

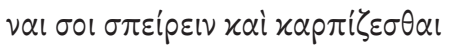

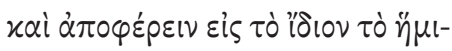

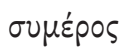

66 Manigk Gläubigerbefriedigung (supra, n. 2), p. 49.

67 Manigk, Gläubigerbefriedigung (supra, n. 2), p. 49; Kupiszewski, Quelques remarques (supra, n. 2), p. 231; Kaser, Besitzpfand (supra, n. 2), p. 87.

68 Cf. P. Oxf. 11 (151 AD, Hiera Nesos). 
I agreed to have received from you in loan from hand to hand out of the house two hundred and forty drachmae a total of $240 \mathrm{dr}$. and in lieu of interest I agreed with you that you could sow the lands, reap the fruits and alienate them to your own benefit for half a part.

In the case of BGU I 101 the antichretic loan is advantageous for both the creditor and the debtor. Not only did the debtor get the loan he desired, he had no worries about the interest due. Furthermore, he did not have to utilise his land and without doing any work he received half of the revenue from the fruits sold by the creditor. The creditor, on the other hand, can exploit the land and if done properly his earnings could have exceeded the maximum interest rate of one drachma per mina per month. The facts from the contract of BGU I 101 show great similarity to D. 20,1,11,1 by Marcianus cited above, which is the leading fragment on antichresis on Roman immovable property (land and houses). For a loan, in this case 240 drachmae, interest is received from the fruits of the object under antichresis ( $\dot{v} \tau i \tau \hat{\tau} \omega \nu \tau o v i \omega \nu \tau o ́ x \omega \nu$ / usuras fructus). In Marc.D. $20,1,11,1$ in order to receive interest the antichresis creditor could firstly utilise an estate by habitation ${ }^{69}$. Secondly, the creditor was entitled to let out the land. Doing so he could collect the rent as civil fruits. The creditor could let the land to a third party ${ }^{70}$, but he could also lease the land back to the antichresis debtor ${ }^{71}$. Thirdly, the antichresis creditor was allowed to cultivate the land himself and harvest the natural fruits. This is also the case in BGU I 101, in which the creditor can alienate the fruits of the land and keep fifty percent of the revenue. Furthermore, Ulp.D. 43,25,1,5 (derived from Jul.D. 8,1,16 which is cited above) shows that the antichresis creditor was entitled to exercise ancillary rights attached to the estate, such as a right of servitude.

\subsection{Slaves}

The most important power of a creditor with a right of antichresis on a slave was to enjoy the services of this slave. This is covered by Diocl.C. 8,42(43),20 and Alex.Sev.C. 4,24, ${ }^{72}$. By extension, the creditor was allowed to educate a slave in a trade. Ulp.D. $13,7,25$ shows that if the creditor had taught the slave a skill, he could reclaim the education expenses. This teaching right of the creditor probably related to the creditor's right to enjoy the slave's services. The text shows that even if there was no agreement between the creditor and the

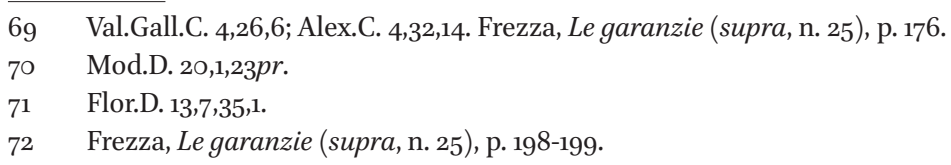


debtor concerning the education of the slave, the creditor could still claim reimbursement for expenses if he had taught the slave a necessary skill. Ulpian did not mention to what end the skill was necessary. However, it is likely that the skill was necessary to enable the creditor to make use of the services of the slave.

On the other hand, in Roman Egypt not only slaves but also free persons and freed persons sometimes were the object of an antichretic loan, which is called paramone $^{73}$. Slaves were, however, much more frequently the object of paramonè than free persons or freed persons. To secure a loan slaves or free(d) persons stayed with the creditor ( $\pi \alpha p a \mu \varepsilon \varepsilon \varepsilon(v)$, so that during the term of the loan the creditor could benefit from the labour of these persons. In P. Diog. 16, 22-23 (207 AD, Krokodilopolis) a slave-girl's service was the object of paramonè to

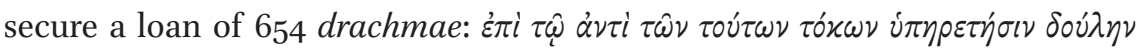

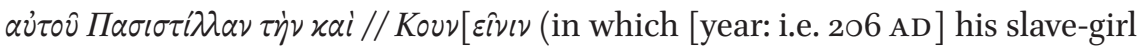
Pasistilla, also known as Kouneinis, served in lieu of interest). This form of antichresis could come from the Attic legal system as it can be found in the speech Against Aphobus by Demosthenes, one of the primary sources of Attic

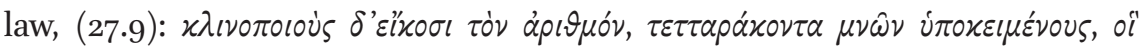

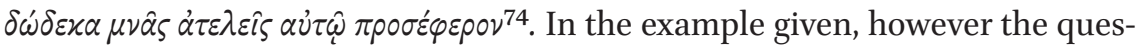
tion remained what was to happen with the twelve minae ( $\delta \omega \delta \delta \varepsilon \kappa \alpha \mu \nu \hat{\alpha} \varsigma)$.

\section{5}

\section{Antichretic functions}

The above shows that the antichresis creditor was entitled to utilise the property given in antichresis. By utilising the property, the creditor could make a profit after deduction of the expenses. The question would then rise whom this profit should benefit. Could the creditor keep the fruits of utilisation, or should he hand them over to the debtor? This question could be answered in the antichresis agreement. If parties agreed that the profit would benefit the creditor, the creditor could keep the fruits in lieu of interest. We define this type of antichresis as interest antichresis. If the profit would benefit the debtor, the

73 In BGU IV 1153 II, 19 (11-10 BC, Alexandria) the debtor's son was the object of antichretic

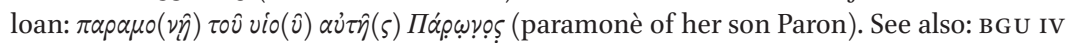
1154 (10 BC, Alexandria) and P. Merton III 105 (164 AD, Tebtynis).

74 Demosthenes 27.9: Slaves to make up the beds twenty in number, securing a credit of forty minae. These yielded him an unburdened sum of 12 minae. The text edition comes from A. Murray, Demosthenes Orations, Volume IV: Orations 27-40: Private Cases, Cambridge 1936, p.12-13. 
creditor should keep the fruits as payment on the secured debt. We define this type of antichresis as amortization antichresis.

\subsection{Interest antichresis}

The twelve minae mentioned in the above text of Demosthenes were handled depending on the conditions set in the contract, which in this legal setting could differ. In most papyrological sources from Roman Egypt, the fruits of this institution were to benefit the creditor as interest e.g., in SB XVI 13042 (29 AD, Oxyrhynchus) and P. Mich. III 118, 7\& 21 (120 AD, Bacchias):

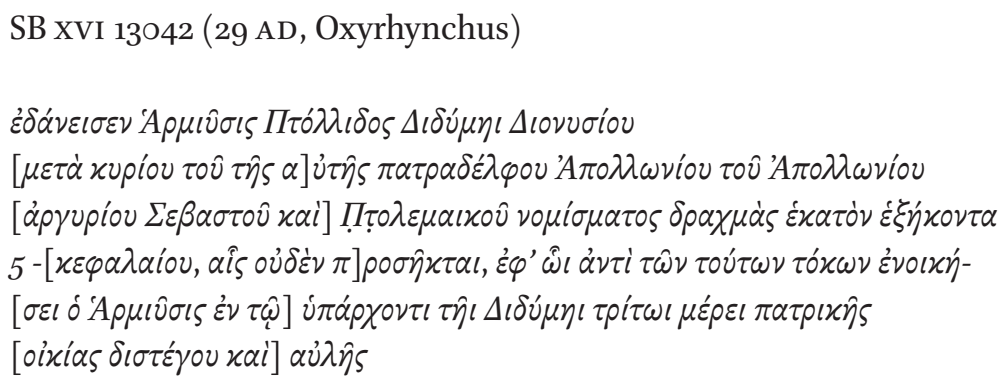

Harmiysis son of Ptollis has agreed upon a loan with Didyme daughter of Dionysos, accompanied by her guardian Apollonios son of Apollinios her paternal uncle, the principal sum being 16o drachmae in Augustan and Ptolemaic silver coinage, to which nothing has been added, in lieu of interest Harmiysis is granted the right of habitation in a one third share of the two stories house and courtyard which she inherited from her father.

The Roman variant of interest antichresis is covered in Alex.Sev.C. 4,32,14 and Phil.C. 4,32,17 ${ }^{75}$. When creating this interest antichresis, parties would enter into an antichretic loan. The contracting parties did not stipulate an interest rate on the loan. Instead, they agreed that the antichresis creditor would keep the fruits in lieu of interest. Thus, the creditor's compensation for lending out his money was equal to the yield of utilisation of the antichresis property. The creditor could keep the fruits as compensation for his inability to use the funds lent to the debtor ${ }^{76}$. The value of the fruits did not diminish the nominal value of the secured debt. Therefore, the interest antichresis was advantageous to

75 See also Marc.D. 20,1,11,1; Val.Gall.C. 4,26,6. Both texts are cited above.

76 The wording of this sentence is derived from A. Titus, The different permutations of csARs $v$ Brummeria, Was it something other than an 'interest-free' loan?, South African Law Journal, 2012, p. 244. 
the creditor, provided that the value of the fruits exceeded the competitive interest rate ${ }^{77}$.

Since the antichresis creditor kept the fruits in lieu of interest, the interest antichresis was subject to the Roman laws of usury. Therefore, the value of the fruits was not allowed to exceed the maximum interest rate of $6 \%$ of the principal sum ${ }^{78}$. Should the value of the fruits exceed this maximum interest rate nevertheless, the surplus would be imputed on the principal sum ${ }^{79}$. An exception to this rule was made, if the 'value' of the fruits could not be expressed in money or the value of the fruits differed from year to year ${ }^{80}$.

This exception could provide for a legal way to circumvent the maximum interest rate. If a right of antichresis was created over an object which by nature produced an uncertain value, no fruits had to be imputed on the principal sum. Instead, the creditor could keep the fruits, even if the total amount exceeded the maximum interest rate. An example is given by Alex.Sev.C. 4,32,14:

Si ea pactione uxor tua mutuam pecuniam dedit, ut vice usurarum inhabitaret, pactoque ita ut convenit usa est, non etiam locando domum pensionem redegit, referri quaestionem, quasi plus domus redigeret, si locaretur, quam usurarum legitimarum ratio colligit, minime oportet. licet enim uberiore sorte potuerit contrahi locatio, non ideo tamen illicitum fenus esse contractum, sed vilius conducta habitatio videtur.

If in this agreement your spouse gave money as a loan for consumption, in order that she had the right of habitation instead of interest, and she made use of this agreement as convened and she, however, did not collect rent by renting out the house, then by no means must the question be raised, whether the house would have yielded more than the sum of legitimate interest would have collected, if it were rented out. Even if a contract of lease could be entered for a more copious amount, the contract of loan would still not be entered unlawfully, but the right of habitation would appear to be contracted for a rather low amount.

77 Kohler, Pfandrechtliche Forschungen (supra, n. 46), p. 73; Manigk, Gläubigerbefriedigung (supra, n. 2), p. 55-57; Kaser, Besitzpfand (supra, n. 2), p. 83.

78 Just.C. 4,32,26,1; Just.C. 4,32,26,2; R. Zimmermann, The law of obligations, Roman foundations of the civilian tradition, Oxford 1996, p. 168-169.

79 Cf. Just.C. 4,32,26,4.

80 Alex.Sev.C. 4,32,14 and Phil.C.4,32,17; Kohler, Pfandrechtliche Forschungen (supra, n. 46), p. 109-110; Manigk, Gläubigerbefriedigung (supra, n. 2) p. 55-57; Kaser, Besitzpfand (supra, n. 2$),$ p. 83 . 
In this fragment, a right of antichresis was created over a house. The creditor exercised his right of antichresis by inhabiting the house. Apparently, the value of letting the house exceeded $6 \%$ of the principal sum. Still, the creditor did not have to impute anything on the principal sum, since the value of inhabitation by the creditor was not expressed in money. Therefore, the house was deemed to have been rented to the antichresis creditor for a rather low rent which did not exceed the maximum interest rate of $6 \%$ of the principal sum ${ }^{81}$.

\subsection{Amortization antichresis}

Antichresis could function as a replacement for interest. The fruits of an antichretic loan, however, could also be deducted from the principal sum (amortization antichresis). If the principal sum would bear interest, the value of the fruits would primarily be deducted from the interest due, after which any surplus would be deducted from the principal sum. Should the value of the fruits be smaller than the interest due, the interest that remained after deduction was still due. In P. Yale I 68, 23 (204 AD, Oxyrhynchus) ${ }^{82}$ the interest, which in this case has been set on 13 drachmae a year (1. 39), is taken from the yield. Any fruits remaining were deducted from the principal sum. This settlement was conducted on a yearly basis: $\varkappa \alpha \tau^{\prime}$ हैं

Also, sometimes in case of non-payment the antichresis creditor could initiate real execution of the object of an antichretic loan, as well as other assets in the estate of the debtor. This is for example attested in P. Mich. X 585 ( $87 \mathrm{AD}$, Bacchias) ${ }^{84}$ and P. Hamb. I 30 (89 AD, Philadelphia). In P. Princ. III 144 (219-220 AD, Ptolemais Euergetis) the object, which was half a part of a house near the village of Philadelphia, is forfeited to the creditor as if it were a forfeiture pledge, showing that antichretic loan at least in Roman Egypt had features of a ius in $r e^{85}$.

$81 \quad$ Manigk, Gläubigerbefriedigung (supra, n. 2), p. 55-57.

82 See D. Hagendorn, J. Thomas, Eine Neuedition von P.Yale I 68, ZPE 11 (1973), p. 140-141.

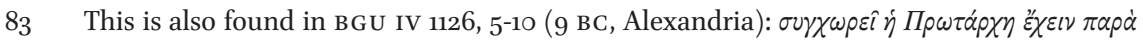

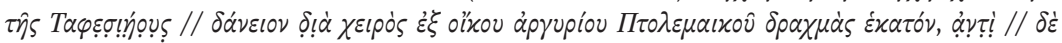

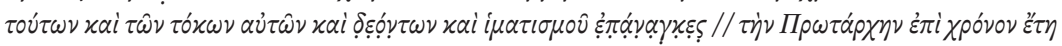

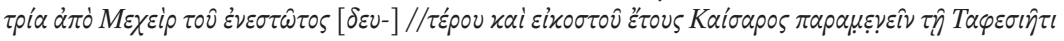

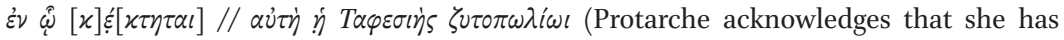
received a loan from Taphasies from hand to hand out of the house hundred Ptolemaic drachmae in silver coinage, in lieu of interest of the loan and the indebted amount and the clothing it is necessary that Protarche remains with Taphasies for three years from the month Mecheir of the present year being the twenty second year of the reign of Caesar, in whose beer shop she is to be used). Cf. Manigk Gläubigerbefriedigung (supra n. 2), p. 28.

$84 \quad$ In this case execution of all the belongings of the debtor by the creditor was allowed.

85 Cf. BGU VI 1280 (III AD, provenance unknown). 
The previously discussed Roman amortization antichresis is addressed in Sept.Sev.Ant.Car.C. 4,24, ${ }^{86}$. Here, the creditor granted an interest-bearing loan to the debtor. When securing this loan with an amortization antichresis, parties agreed that the creditor should keep the fruits as payment on the secured debt. The interest due would first be taken from the fruits. If the value of the fruits exceeded this interest (or if no interest rate was stipulated), the residue would be imputed on the principal sum. If the amount was enough to even extinguish the principal sum, the antichresis creditor had to return any remaining fruits to the debtor together with the pledged object itself. Failure to do so would render the creditor liable with the actio pigneraticia directa ${ }^{87}$.

If, however, the value of the fruits was smaller than the amount of interest due, the creditor was entitled to the difference. In an amortization antichresis, the value of the fruits did diminish the secured debt. Thus, contrary to interest antichresis, the debtor's debt was decreased by the value of the fruits. Therefore, the amortization antichresis was advantageous to the debtor.

Amortization antichresis shows two more reasons for creating a right of antichresis ${ }^{88}$. Firstly, the debtor could create a right of antichresis over a fruitbearing asset in order to pay back his debt. If the debtor did not have sufficient funds to meet his obligations under a debt, he could create a right of antichresis over a fruit-bearing asset. The creditor would then be repaid out of the fruits of the pledged object, instead of receiving monetary payment by the debtor ${ }^{89}$. Secondly, antichresis could be an interesting alternative to sale under execution. In the event of a decline in prices of the security object, execution sale may not have been an attractive option to the secured creditor. By selling a security object with a lesser value than the loan it secured, the creditor's claim was not entirely satisfied out of the proceeds and he was unlikely to recover this residual debt. Instead of auctioning off the object of security, the creditor could exercise the right of antichresis ${ }^{90}$. He could utilise the security

86 See also Pap.D. 6,1,65pr.; Mod.D. 13,7,39; Tryph.D. 20,5,12,1; Alex.Sev.C. 4,32,12(11); Alex. Sev.C. 4,24,2; Alex.Sev.C. 4,24,3; Diocl.Max.C. 4,24,12; Alex.Sev.C. 8,27(28),1.

87 Marc.D. 13,7,33; Ulp.D. 36,4,5,21; Sept.Sev.Ant.Car.C. 4,24,1; Diocl.Max.C. 4,24,12; Diocl. Max.C. 8,24(25),2; Alex.Sev.C. 8,27(28),1; Kohler, Pfandrechtliche Forschungen (supra, n. 46), p. 71 and 93; Frezza, Le garanzie (supra, n. 25), p. 57-58. F.B.J. Wubbe, Res aliena pignori data, De verpanding van andermans zaak in het klassieke romeinse recht, diss. Leiden: 196o, p. 150-151; Kaser, Besitzpfand (supra, n. 2), p. 87; G.H. Potjewijd, Beschikkingsbevoegdheid, bekrachtiging en convalescentie, Een romanistische studie, Deventer 1998, p. 44-45.

88 This paragraph is inspired by M. Kaser, Partus Ancillae, zSR 75 (1958), p. 191-192; Kupiszewski, Quelques remarques (supra, n. 2), p. 234.

89 An example might be attested in Mod.D. 13,7,39.

90 Pap.D. $20,1,1,3$. 
object and take the fruits thereof in reduction of the secured debt. Thus, the creditor could gradually satisfy his claim. When his claim had diminished enough, the creditor could still decide to satisfy the remainder of his claim by execution sale ${ }^{91}$.

\section{The contractual position}

\subsection{Classical Roman law}

A Roman right of antichresis put three duties on the antichresis creditor. Firstly, the antichresis creditor had to comply with the pledgee's duty of care. The application of the general duty of care of the pledgee to the antichresis creditor is attested in Alex.Sev.C. 4,24,3 and Ulp.D. 13,7,24,3. These texts show that if a pledgee damaged a field in cultivating it, he was liable for the damage caused with an actio pigneraticia directa. This liability probably did not hold if the damages were caused by natural wear and tear. Ulpianus held that the borrower of a thing for use (commodatarius) was not liable for any deterioration of the object arising from wear and tear through normal use ${ }^{92}$. By analogy, the same should apply if the pledgee used the security object in a duly authorised manner ${ }^{93}$. On the other hand, if a pledgee would gravely abuse his powers of antichresis, for example by prostituting a slave, the right of pledge would even be extinguished: 'pignus solvitur'. It is likely that the debtor of an independent right of antichresis could sue for damages with an actio pigneraticia directa utilis. The debtor might even bring an actio furti ${ }^{94}$.

Apart from this duty of care, there were two more obligations that were only applicable if the function of the created antichresis was amortization. Firstly, the creditor had to return any remaining fruits together with the pledged object to the debtor when the secured debt was paid, as set out above. Furthermore, the antichresis creditor did not only have the power to utilise the goods he had in antichresis, he was under a duty to do so. In Alex.Sev.C. 4,24,3, a creditor had a right of pledge over an estate. The outstanding amount of the secured debt was reduced with the value of the fruits that were reaped by the pledgee, as well as the fruits that should have been reaped. A similar opinion was given in Diocl.Max.C. 8,24(25),2: A pledgee of a slave was obliged to reduce the secured debt by the value of the slave's services that he enjoyed or should

\footnotetext{
$91 \quad$ Ulp.D. 36,4,5,21; Manigk, Gläubigerbefriedigung (supra, n. 2), p. 61-64; Kaser, Besitzpfand (supra, n. 2), p. 84-85.

92 Ulp.D. 13,6,10; Zimmermann, The law of obligations (supra, n. 78), p. 195.

93 Cf. Zimmermann, (supra, n. 78), p. 225-227.

94 Compare Gai.Inst. 3,195-3,197, Just.Inst. 4,1,6-4,1,7.
} 
have enjoyed. Thus, Alex.Sev.C. 4,24,3 and Diocl.Max.C. 8,24(25),2 show it was mandatory for an antichresis creditor to use antichresis property and draw its fruits. The value of the use and the fruits would benefit the debtor by going in reduction of the secured debt. If the creditor was negligent in his utilisation of the antichresis property, the secured debt would be reduced by the value that the creditor reasonably could have realised ${ }^{95}$. The pledgee could also be liable for damages if not using the property lead to a decline in value of the property. For example, if a pledgee failed to use a servitude that was ancillary to immovable property that was pledged to him, this servitude could extinguish due to non-usus. This would lead to a decrease in value of the immovable property, for which the pledgee would be liable ${ }^{96}$. These last two obligations were only applicable to the amortization antichresis ${ }^{97}$, since in an interest antichresis all the fruits drawn by the creditor would come in lieu of interest, no matter how high the yield was. In this case the way in which the creditor utilised the antichresis property was of no significance to the debtor.

\subsection{The contractual practice}

The papyri regarding antichretic loans do not contain clauses that obligate the creditor to use the objects under this legal institution, but only create the power to do so. This, however, is unproblematic, because the majority of antichretic documents concern interest antichresis. In ll. 9-10 of the earlier cited P. Yale

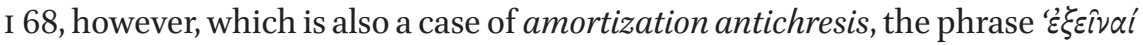

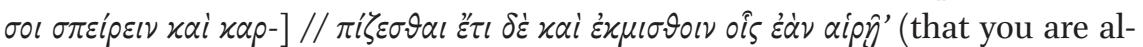
lowed to sow the land and reap the fruits or lease it out to whom you may prefer) implies that there is no obligation of actually utilising the antichresis property.

Furthermore, penalty clauses and clauses concerning damages and other restrictions are mostly directed towards the debtors. The contract BG U IV 1053, cited above, has commonly used penalty clauses towards the debtors written from ll. $28-56$ on col. I and ll. 1-13 on col. II, such as a non-alienation clause ${ }^{98}$, a fifty percent fine and interest of an amount of drachmae per mina in case of late payment ${ }^{99}$, seizure and arrest of the debtors, the right to execution on

95 Cf. Kohler, Pfandrechtliche Forschungen (supra, n. 46), p. 70.

96 See for example Ulp.D. 13,7,15; Ulp.D. 43,26,8,5.

97 Kohler, Pfandrechtliche Forschungen (supra, n. 46), p. 217.

98 This non-alienation clause can also be found in the above cited P. Princ. III 144, which is later than the constitutio Antoniniana. One of the contractual parties is a seventy year old Roman veteran named Aurelius Diogenes.

99 Cf. P. Fouad 44 (44 AD, Oxyrhynchus), in which a Roman contracting party is featured named Lucius Pompeius son of Lucius from the tribus Pollia. 
each of the three debtors and all their belongings and a clause revolving all risks unto the debtors. By means of these contractual clauses the creditor and debtor have an unequal legal position, in which there is almost no protection for the debtor. Also in the papyri published no provisions can be found that creditors must pay for damages inflicted on the objects under antichretic loan ${ }^{100}$.

\subsection{Comparison}

The above shows that in Roman law protective measures were taken in favour of the debtor of an antichretic loan. The debtor was protected against misuse of the antichresis object made by the creditor. The other protective measures only concerned amortization antichresis: the creditor was obliged to restore any remaining fruits and he was even obliged to utilise the antichresis property. The rule that interest antichresis was subject to the Roman laws of usury might also be viewed as a measure protecting the debtor against a creditor gaining an unfair advantage from utilising the antichresis property. None of these protective measures were present in the papyrological sources from Roman Egypt we studied. On the contrary, if any additional clauses were included in an antichresis contract, they favoured the creditor rather than the debtor.

Perhaps the absence of measures protecting the debtor in papyri could be explained by the protection given by the law, and vice versa. Contracting parties might not deem contractual protection of the debtor necessary, since the protection was already granted by operation of law and was safeguarded by the praefectus aegypti, whose powers were similar to the powers of the praetor in Rome. On the other hand, the legislator in Rome of the third century could have decided to protect the antichresis debtor, since antichresis contracts were largely favouring the creditor.

This latter scenario occurred in Byzantium in the sixth century. Justinian took several measures to protect debtors against exploitation by powerful creditors. Firstly, he criminalised the practice of giving free children in antichresis to the creditor in Just.Nov. 134,7, as discussed above. Secondly, he prevented abusive overinsurance of creditors ${ }^{101}$. Apparently, creditors demanded possessory pledges over the estates of their debtors to secure a very small loan of fruits. The creditors thus chased away the debtors from the estate, probably

\footnotetext{
100 In papyri containing żvoíx $\eta \iota \varsigma$, possible damages to the house, paid by the creditor were to be reimbursed by the debtor. See for example P. Mich. III 188 \& 189 (both: 123AD, Bacchias). 101 Just.Nov. 32-34.
} 
so they could utilise the estate themselves. Justinian explicitly intervened on behalf of debtors in need of small credit ${ }^{102}$.

Of course from these Novellae we can draw no conclusions on law and practice in the Roman Empire of the third century. The Novellae do, however, make a plausible case for the thought that, as in the sixth century, the Roman chancery created rules to protect antichresis debtors against antichretic loans that were overly favourable to creditors. The protective measures issued in the third century later turned out to be insufficient to protect debtors against abuse by their powerful creditors. This emerges from the sixth century Novellae of Justinian.

\section{Conclusion}

In this article we compared the right of antichresis in classical Roman law with antichresis in the contracting practice emerging from sources from Roman Egypt. This source material shows a remarkable continuity: for every age, contracts on antichretic loans are available between the third century вС up to the Arabic conquest. On the other hand, the presence of antichresis in Roman legal sources shows a discontinuity. The legal concept of antichresis was only mentioned for the first time in the third century AD. Although most of the Roman legal sources concerning antichresis date from the third century AD or later, it is unlikely that antichresis was a familiar legal concept in Rome before this time. Apparently, Romans in Egypt who entered into antichretic contracts from the beginning of the Roman conquest of Egypt did not bring antichresis to the Italic peninsula. The legal concept of antichresis not only made its first appearance in Roman legal sources in the third century, it was dealt with in many rescripts and advices dating from this century. Antichresis is again absent in Roman sources from the fourth and fifth century. Antichresis then reappeared in the sixth century in Justinian's Novellae. These sixth century sources give rise to the suspicion that abuse of antichresis had been building up to the sixth century, perhaps even in the fourth and fifth century. It is unclear why antichresis was mentioned by so many in the third century, and by none in the two following centuries. One possible explanation could be that one century of rescripts and advices on antichresis had finally provided clarity on this legal concept. Another explanation is that sources in the Corpus Iuris Civilis are scarce in general. We were not able to establish a mutual influence of

102 This reading was suggested by U. Huber, Praelectionum juris civilis Tomus III, Napoli: Roland 1788, nr. 20.1.15. See also Patlagean, Pauvreté (supra, n. 28), p. 254, 266 and 353-354. 
sources from the hellenised Roman East and Roman sources from the Italic peninsula, given the difference in continuity of the source material.

The one substantive difference between Roman-Egyptian antichresis and Roman antichresis, is that Roman law made measures to protect the debtor, whereas in Roman Egyptian antichresis contracts, from the sources studied, the position of the creditor was largely favoured. This difference could be selfexplanatory: the antichresis debtor was protected under Roman law, because antichretic contracts did not provide for such protection. An explanation the other way around is also feasible: Roman Egyptian antichresis contracts favoured the position of the creditor because provincial law issued by the praefectus Aegypti or in guidelines such as the Gnomon of the Idios Logos strengthened and protected the position of the debtor.

Still, the figures of antichresis emerging from the practice in Roman Egypt and classical Roman law are quite alike. They could be established in the same forms: as an independent legal concept or combined with the right of pledge. Furthermore, antichresis from Roman Egypt and Roman antichresis were created on the same objects: slaves, estates and limited real rights thereon. Moreover antichresis could fulfil the same two functions in Rome and Roman Egypt: interest antichresis and amortization antichresis. Given the resemblance in the content of Roman antichresis and antichresis from Roman Egypt, a common origin of the two legal concepts is plausible.

On the other hand, in order to secure credit with antichresis, contractual parties used assets that were easily utilised without rapid devaluation. These assets, such as estates and slaves, were common in the Mediterranean world: both in the Greek-Hellenistic sphere of influence, Roman Egypt and the Italic peninsula. The similarities of the Mediterranean economic world could have evoked the emergence of antichresis in separate legal systems, without these legal systems influencing one another. This could explain the rise of antichresis in the different legal systems of the pan-Mediterranean world. 